\title{
SESN1 wt Allele
}

National Cancer Institute

\section{Source}

National Cancer Institute. SESN1 wt Allele. NCI Thesaurus. Code C137979.

Human SESN 1 wild-type allele is located in the vicinity of $6 q 21$ and is approximately 108 $\mathrm{kb}$ in length. This allele, which encodes sestrin-1 protein, is involved in stress response signaling. 